\title{
In memoriam: Nikola Skledar (1942. - 2011.)
}

7. 11. 2011., nakon teške bolesti, napustio nas je Nikola Skledar, naš dragi kolega, prijatelj, suradnik, dugogodišnji ravnatelj Instituta za društvena istraživanja u Zagrebu, u kojemu je ostavio trajni trag i spomen.

Stara filozofska mudrost kaže da se o čovjekovu životu ne može donositi sud sve do časa njegove smrti. Tek kad se konačno zatvori životni krug, kada nestanu sve mogućnosti koje svaki ljudski život u sebi latentno nosi, tek se tada može pitati o ispunjenju onoga što je bilo dato kao mogućnost, kao zadatak, ili kako kaže Pindar, da se životom "iscrpi polje mogućega". Mislimo da je Nikola Skledar u najvišem intenzitetu i smislu ispunio životni zadatak i, čak štoviše, postavio ga na visinu uzora.

Sjećanje je ovo na iznimnog intelektualca i nadasve dobrog čovjeka, vedrog, tolerantnog i uvijek spremnog na pomoć, kao i za razumijevanje drugog.

Pokušaj je to da se u najkraćim crtama naznači ličnost Nikole Skledara u njegovom filozofskom, znanstvenom i ljudskom djelovanju i značaju.

Njegov ogroman opus tek čeka svoje istraživače, a skup brojnih ljudskih vrlina kojima je zračio i nesebično ih rasipao, čine njegov jedinstven ljudski i filozofski ethos. Sve to nije moguće obuhvatiti u ovoj prilici. Značenje jednog čovjeka prostire se toliko daleko koliko je u stanju radijus svoga duha i osobnosti stvaralački i humano širiti na druge ljude. A Nikola je neprestano i neumorno širio svoje krugove, uvijek s osnovnim filozofskim ciljem: pridonijeti humanizaciji svijeta i čovjeka. Taj leitmotiv provlači se kroz sva njegova djela.

(Životopis koji slijedi sam je napisao za svoju posljednju knjigu Sociologija kulture.)

Nikola Skledar rođen je 1942. u Zaprešiću. Gimnaziju je završio u Zagrebu, gdje je i diplomirao filozofiju i psihologiju na Filozofskome fakultetu.

Odslušao je poslijediplomski studij Teorije religije $i$ ateizma pri Institutu za društvena istraživanja Sveučilišta u Zagrebu, a doktorirao na Fakulteti za sociologijo, politične vede in novinarstvo Univerze v Ljubljani.

Radio je na Filozofskome fakultetu (Sveučilištu) u Zadru, od asistenta do redovitoga profesora u trajnome zvanju, gdje je obnašao dužnost predstojnika Odsjeka za 
sociologiju i pročelnika Zavoda za filozofiju, sociologiju, psihologiju i pedagogiju. Bio je dugogodišnji ravnatelj Instituta za društvena istraživanja u Zagrebu, a prije svoga konačnoga odlaska dekan Visoke škole za poslovanje i upravljanje "Baltazar Adam Krčelić" u Zaprešiću.

Predavao je na poslijediplomskim studijima sociologije na Filozofskome fakultetu u Zagrebu, bio je kodirektor poslijediplomskoga tečaja Future of Religion Interuniverzitetskoga centra (IUC) u Dubrovniku i zamjenik voditelja poslijediplomskoga studija Kultura i društvo Sveučilišta u Zadru. Pod njegovim je mentorstvom izrađeno nekoliko magistarskih i doktorskih radova. Održao je mnoga javna predavanja diljem Hrvatske i u inozemstvu.

Bio je aktivni sudionik domaćih i međunarodnih znanstvenih skupova, voditelj znanstvenih programa i projekata, urednik znanstvenih časopisa i biblioteka. U nekoliko mandata bio je član Predsjedništva Hrvatskoga sociološkog društva te predsjednik Hrvatskoga filozofskog društva i Hrvatskoga bioetičkog društva.

Autor je osamnaest autorskih knjiga i preko stotinu znanstvenih i stručnih radova u zemlji i inozemstvu.

Kao što prethodno pokazuje, znanstveno i filozofsko djelo, kao i ukupno djelovanje Nikole Skledara je ogromno. Ono sâmo govori o silnoj intelektualnoj i životnoj energiji koja je bila potrebna za ovako bogat stvaralački život. Njegov ukupan filozofski i znanstveni opus, kao i javno i društveno djelovanje, trajno su obilježili našu filozofsku i znanstvenu misao, ali i kulturu u najširem smislu. Vrednovanje ovog plodnog i svestranog intelektualca i njegova života, zahtijevat će dugotrajan i interdisciplinaran istraživački rad: ne samo stoga što se u Skledarovim knjigama pojavljuju brojne znanstvene discipline i područja, kao što su filozofski, sociološki, psihološki i antropološki aspekti religije, filozofije, antropologije, psihologije, sociologije i filozofije kulture, odnos znanosti i filozofije i dr., nego i s obzirom na činjenicu da je izgradio osebujnu i originalnu koncepciju fenomenologijske, egzistencijalne i dijalektičke socio-kulturne antropologije, sa stalnim propitivanjem njezinih osnova unutar jedne fundamentalne filozofske antropologije. U tom je smislu Skledar utemeljitelj jednog novog poimanja, ne samo antropologije, nego i novog položaja i suradnje društvenih i humanističkih disciplina.

Ukoliko bi se htjela naći značajka koja u najvećoj mjeri sažima njegovu duhovnu bit i intelektualnu energiju, onda bi se ona vjerojatno mogla prepoznati u jednoj naročitoj vrsti duhovne koncentracije, napregnutosti i lucidnosti, koju je zadržao do samoga kraja, kada je, samo nekoliko dana prije svoga odlaska, još radio neke manje preinake na rukopisu svoje posljednje knjige o sociologiji kulture.

Neprestana je njegova usmjerenost, ne samo na ono bitno, nego i zahvat prodornog pogleda u transcendentalno polje, kojemu se uvijek vraća, u horizont smisla, njegovog "nabacivanja" u buduće, prekoračivanja. "Misliti znači transcendirati" (prekoračivati), rekao je filozof nade E. Bloch. To znači sa strašću nadmašivati samoga 
sebe. I upravo je Nikolina stalna i koncentrirana napregnutost mišljenja, njegova istinska strast, strast humanuma. To svjetlo humanuma, koje on uvijek doživljava kao svjetlo na horizontu kojemu se približavamo, ali ga nikad ne dostižemo, slika je njegove vlastite čežnje za smislenim ljudskim putovanjem. Ova transcendentalna osnovanost njegova mišljenja, ujedno je i Skledarovo vlastito filozofsko polazište, u nemiru. Iz njega, uvijek iznova, s istom strašću, prodornošću, traga za onim što mu je najvažnije: za uvijek novim mogućnostima čovjeka, kroz njegovu stvaralačku bit, ali ne samo kao jedan znanstveni program otkrivanja istine o čovjeku, nego iz iskonske intencije njegova mišljenja, kao put prema čovjekovoj humanitas. To je prava i najvrednija ontološka točka, koja svijetli na obzoru, kojoj se čovjek treba stalno približavati. Iz takvog filozofskog stava proizlazi i cjelokupna njegova metodologija i izgradnja jedne nove i originalne koncepcije mišljenja o čovjeku, nove antropologije. Ona u sebi treba uključivati multidisciplinarnost, interdisciplinarnost, povijesnost, filozofsku refleksiju, kao i srodne društvene i humanističke discipline. Sve je to kod Skledara uključeno u znanstveni program. Pojmovi smisla i razumijevanja, koji konstituiraju čovjekov duhovni svijet, određuju i načine (metode) njegove znanstvene refleksije: zato inzistira (ustrajava) na refleksivnosti, transcendentalnom, na humanističkom određenju društvenih znanosti (sociologije, antropologije) o čovjeku, na dinamičkoj i povijesnoj njegovoj problematizaciji, na uvijek prisutnoj filozofskoj odredbi humanitasa, na izvorno grčkom određenju čovjeka kao skupa vrlina. Zato, s pravom, inzistira na specifičnom položaju društvenih i humanističkih znanosti, koje imaju druge duhovne i istinosne zadatke: one koji, uz pomoć filozofije kao mišljenja cjeline, pokušavaju čovjeka odrediti i usmjeriti prema njegovu smislu. Čuvaju pojam njegove čovječnosti, jer bez nje su svi rezultati tzv. pozitivnih znanosti samo zastrašujuća slika njegove pervertiranosti i izgubljenosti. Zato je Skledarova misaona strast uistinu humanistička, dakle, ne tek znanstveni posao, nego poziv odgovornog inteklektualca, odgovornog za svijet koji treba biti ljudski. I upravo u ovoj točci razabire se bitna razlika znanstvenika i intelektualca, napose u društvenim i humanističkim znanostima: izvrsnost se ne sastoji samo u otkrivanju/prikazivanju spoznaja postojećeg, nego i u kritičkoj refleksiji ovih spoznaja, sabiranja smisla čovjekova postojanja i čuvanja (od zaborava) pojma čovjek.

Jedna od njegovih izrazitih osobina, bila je naglašena tolerantnost prema drugačijem mišljenju i stavu, pogledu ili svjetonazoru. Izuzetak od toga bilo je ponašanje koje ukida sam pojam tolerancije. To je bilo sukladno njegovu poimanju biti filozofije i njezina smisla, na putu osvajanja humaniteta čovjeka: jedini pravi put je put dijaloga (dia-logos), kao umnog napredovanja prema susretu svjesnih bića, ili "podudaranju svijesti" (Hegel). Na tom je principu ustrajavao čitav život i tako se ponašao. I u privatnim odnosima, a to znaju svi koji su ga poznavali, imao je izvanredno razumijevanje za druge, tolerantnost, a njegova spremnost na pomoć i razumijevajuća otvorenost za probleme drugih, kod njega su uvijek bili prisutni. Često je i svojom vedrom, optimističkom prirodom, otklanjao teškoće koje su se činile nepremostivim. Uvijek je djelovao humano, u skladu sa svojim ljudskim ethosom i uvjerenjem, onim što čini filozofsku bit čovjeka, skup najviših vrlina. I upravo iz ove cjelovitosti djelovanja, ono se nadaje tako prirodno, blisko i istinito. 
Nikola je uvijek i dosljedno djelovao prema misaonom zahtjevu, koji je postavio filozof D. Hume, da filozof i usred čitave svoje filozofije treba biti i ostati čovjek.

Dosljedno svojoj filozofskoj naravi, Skledar je stalno i uporno protiv svakog dogmatizma, a to znači isključivosti. Takvo je stajalište suprotno biti filozofije koja traga za istinom, a ne posjeduje ju. Svako dogmatsko mišljenje, naprotiv, misli da istinu već posjeduje. Takvo je stajalište negacija onog najdragocjenijeg, ontološkog i utopijskog u ljudskom biću i njegovoj povijesti: mogućnosti da svojim stvaralaštvom mijenja sebe i svoju povijest, svoj svijet, da je kao biće otvoreni horizont za neslućene pothvate svojih još nedosegnutih mogućnosti. Skledar je bio ustrajan, neumoran i hrabar moreplovac na toj plovidbi.

Nikolina strast za istraživanjem, za vlastitim razvojem, za radom na sebi, kroz napor pojma/mišljenja, pokazuje se u stalnom, intenzivnom praćenju recentne literature na brojnim disciplinarnim područjima, koja ulaze u problematski sklop njegovog filozofskog i znanstvenog rada: sociologije, filozofije, antropologije, psihologije, kulturologije, religijskih teorija i istraživanja, teorija umjetnosti, medija, bioetike i dr. Širina njegovih znanstvenih prodora u raznolika područja društvenih i humanističkih disciplina upravo je zapanjujuća. To nije tek puka obaviještenost, nego niz temeljitih i produbljenih studija o najrazličitijim problemima čovjekovog postojanja. Ne samo da prati najnoviju literaturu, nego intenzivno i kontinuirano piše kritičke studije, te preispituje prethodne spoznaje i, sa začuđujućim intenzitetom, neprestano dalje razvija uvijek nove znanstvene hipoteze i filozofske sinteze.

I posljednji rukopis o sociologiji kulture, nad kojim je bdio do samoga odlaska, pokazuje koliko je pojam kulture zaokupljao njegov duh. U njemu prepoznaje zahtjev filozofskog duha, da čovjek svojim radom duha, obrazovanjem duha, oblikuje sebe kao humano biće. Kultura je ovdje shvaćena kao sabiranje onog najboljeg i najvrednijeg u čovjeku, kao obrazovanje plemenitosti njegova duha. Nikola je dostigao to plemstvo svojim neumornim radom i izgradio uzor.

Oproštajno pismo Nikole Skledara, pročitano na ispraćaju, kojim se toplim riječima on oprašta od svih s kojima je dijelio život, u raznim njegovim razdobljima, predstavlja jedinstven, dirljiv primjer plemenitosti ovoga duha, pokazuje svu pažnju, obzirnost i tankoćutnost, koje je toliko često poklanjao drugima. Pokazuje dostojanstvo, hrabrost i svijest, da je svojim životom i radom, ispunio smisao koji mu je dat kao zadatak. Nikola je u sebi spajao antitetičke suprotnosti, a ipak je uvijek težio za harmonijom: ona je sinonim ispunjenja i sreće. Čitanje njegovog oproštajnog pisma pogodilo je prisutne svojom jedinstvenom, strahotnom snagom, gotovo epifanijski omamljujućom, ozbiljnošću neizrecive svečanosti i svetosti tona, u auri uzdignuća i odlaska, urezanog u naše sjećanje, čini se, zauvijek.

Ako nam je dopušteno maštati, nama, koji smo ga blisko poznavali, nije mogla promaknuti nevidljiva naznaka nestašnog bljeska, izazova, nekog tračka nade, da ćemo se, možda, ipak, ponovo naći na nekoj nebeskoj veselici... 
Kad smo se opraštali, bio je predivan, sunčan i prohladan, jesenji dan, 11. 11. 2011., u sredini svoje neponovljive ljepote. Svjetlo je tada bilo najintenzivnije. A kada je završila ceremonija oproštaja na grobu, sunce se naglo, neprimjetno sakrilo, tiho potonulo, a oštri, ledeni sumračak stao je sipiti u naše oči. No mi ga nismo vidjeli očima, naša su ga srca prepoznala. I učas, energija sjećanja prelije toplinom ovu, trenutnu, nesvjesticu, i sjetimo se kontrapunkta, sreće, da smo dio svoga života dijelili s tim izvanrednim čovjekom, istinskim filozofom i znanstvenikom Nikolom Skledarom. Odlazimo s toplinom u srcu, s poštovanjem i obećanjem da ćemo u srcu i mislima i dalje biti zajedno.

Pokušao sam podijeliti sjećanja, osjećaje i poštovanje prema prijatelju Nikoli Skledaru, sa svima koji su ga imali sreću i čast poznavati, onakvog kakvog ga pamtim. Zasigurno svatko ima svoja osobna sjećanja i osjećanja, a to, naravno, ostaje pohranjeno u svakom srcu i misli, kao vlastita dragocjenost jednog razdoblja našeg života, u kojem lik Nikole Skledara svijetli svojom dobrotom i umnošću.

Mladen Labus 